\title{
The Economic Development of Bau-Bau City and the Strengths of its Hinterland
}

\section{Muhammad Agung Ady Mangilep', Anas Iswanto Anwar ${ }^{2}$ and Adelia Undangsari Ady Mangilep ${ }^{3}$}

\author{
${ }^{1}$ Hasanuddin University, Indonesia, e-mail: agungam@,fe.unhas.ac.id \\ ${ }^{2}$ Hasanuddin University, Indonesia, e-mail: aianwar@fe.unhas.ac.id \\ ${ }^{3}$ Hasanuddin University, Indonesia, e-mail: adeliady@unhas.ac.id
}

\begin{abstract}
This research is aimed to explore the potential relation between Baubau City and its hinterlands to improve their economies. This research uses quantitative data obtained from a series of Indonesian government's publications. LQ method is used to analyze basic sectors in the economy and descriptive statistics is used to analyze economic relation of hinterlands. This research finds that Baubau City growth can be increased by an improvement of a regional economy, especially by expanding several basic sectors.

Keywords: regional development, hinterland, basic sector
\end{abstract}

\section{Introduction}

Baubau City serves as a transit city for Indonesian's sea transportation system. Baubau City was a part of a main business transportation route from the western Indonesia to the eastern one which induced the city growth. However, the role of sea transportation as a passenger transportation has decreased in this recent 2 decades. It was happened because of a declining trend of airfares and a price stability of vessel fares. Recently, air transportation route did not put Baubau city as a transit city for a national air route. A role of Makassar as a main transit city for a national air route cannot be replaced by other cities in the central Indonesia. In order to find consumer goods, people in hinterlands of Baubau City's go mostly to Makassar City in South Sulawesi Province or Surabaya City in East Java Province. Baubau City needs to improve its economy. That improvement should be related to hinterlands. Currently, the development policies of Baubau City are not met the needs of its hinterlands.

This paper is aimed to explore the potential relation between Baubau City and its hinterlands to improve their economies. That relation is shown by sectors in Baubau City which those products can be increased to supply consumer needs in the hinterlands.

A regional aspect of an area development is one of the most important issue for an area growth in a market system. An area can be a center of trading activities while others surrounded relate their economies with the central area. Berliant (2005) describes a central place theory as a hierarchical arrangement of a marketplace in the context of spatial analysis. Nowadays, a hinterland development has become an important aspect in a central area development. Welman and Ferreira (2016) states the importance of port development in a central area in order to reduce poverty and to increase employment in hinterlands. OECD (2008) points out the role of ports as a supply chain to hinterlands. Visser, Konings, Pielage, etc. (2007) focuses on the importance of a port for a hinterland development.

\section{Research Methodology}

Location Quotient or LQ method is used to calculate a share of a part of an object to the object itself. Hanif, Tabassum, Hauque, etc. (2015) applies LQ method to define disparities in a region. Ascani, Crescenzi, Iammarino (2012) uses LQ method to define spatial inequalities. Srotebeck (2010) applies LQ method to define area clusters.

My research uses LQ method to calculate a value which shows a share of a local Gross Domestic Regional Product (or GDRP) to a regional GDRP. 


$$
\mathrm{LQ}=\frac{\frac{x_{i}}{x_{j}}}{/ \frac{x_{i}}{x_{j}}}
$$

where, $x_{i}=$ a GDRP of a sector in a local economy

$x_{j}=$ a total GDRP of a sector in a local economy

$X_{j}=$ a GDRP of a sector in a regional economy

$X_{j}=$ a total GDRP of a sector in a regional economy

If LQ value is higher than 1, it is defined as a basic sector. If LQ value is lower than 0 , it is defined as a non-basic sector. The basic sector grows more than the non-basic sector.

\section{Result and Discussion}

The total GDRP of Baubau City has reached Rp 6,743.8 billion along with a fluctuated growth in the period of 2010-2016 (BPS Baubau 2018). On average, Baubau City's growth is at 12.74 percent. Baubau City's sectoral GDRP on 2016 is shown at Table 1.

Table 1. Sectoral GDRP distribution of Baubau City at current prices on 2016 (BPS Kota Baubau 2018)

\begin{tabular}{|l|r|}
\hline \multicolumn{1}{|c|}{ Sectors } & \multicolumn{1}{|c|}{$\begin{array}{c}\text { GDRP } \\
\text { (Rp million) }\end{array}$} \\
\hline Agriculture & $921,529.87$ \\
Mining & $300,843.85$ \\
Manufacture & $285,734.02$ \\
Electricity and gas & $3,609.60$ \\
Clean water and waste management & $21,842.25$ \\
Constructions & $1,421,976.23$ \\
Retails and car and motorbike repair shops & $1,310,158.17$ \\
Transportation and warehouses & $343,588.79$ \\
Hotels and restaurants & $86,127.83$ \\
Information and communication & $236,187.41$ \\
Finance and insurances & $233,580.54$ \\
Real Estates & $195,238.53$ \\
Enterprises & $10,581.23$ \\
Governmental administration, defense system and social security & $588,503.31$ \\
Educational services & $481,347.52$ \\
Health care and social activities & $80,277.19$ \\
Uncategorized services & $222,721.22$ \\
\hline
\end{tabular}

Distribution of GDRP is also can be presented by its main sectors. On average, the primary sector contributed 19.02 percent from the total GDRP. Secondary sector contributed 28.02 per cent. Tertiary sector contributed 52.96. So that the tertiary sector has played an important role in Baubau economy. Main sectoral distributions of GDRP in the period of 2010 to 2016 is presented in Table 2. 
Table 2. GDRP allocations of Baubau City at current prices (processed data from Table 1)

\begin{tabular}{|l|r|r|r|r|r|r|r|}
\hline \multirow{2}{*}{ Main sectors } & \multicolumn{7}{|c|}{ Years } \\
\cline { 2 - 8 } & \multicolumn{1}{|c|}{2010} & \multicolumn{1}{|c|}{2011} & \multicolumn{1}{c|}{2012} & \multicolumn{1}{c|}{2013} & \multicolumn{1}{c|}{2014} & \multicolumn{1}{c|}{2015} & 18.13 \\
\hline Primary & 19.39 & 18.64 & 19.28 & 19.45 & 19.54 & 18.71 & 28.59 \\
Secondary & 27.69 & 27.98 & 28.13 & 28.22 & 27.54 & 28.01 & 28.28 \\
Tertiary & 52.91 & 53.38 & 52.59 & 52.32 & 52.92 & 53.28 & 53.28 \\
Total & 100.00 & 100.00 & 100.00 & 100.00 & 100.00 & 100.00 & 100.00 \\
\hline
\end{tabular}

Table 3 shows the results of LQ calculations on GDRP of Baubau City in the period 2010-2016. On average, we can see that agricultural sector has an LQ value of 0.57 , so that this sector is categorized as a non-basic one. Mining sector has an LQ value of 0.21 , so that this sector is categorized as a nonbasic one. Manufactured industries sector has an LQ value of 0.69 , so that this sector is categorized as a non-basic one. Electricity and gas sector has an LQ value of 1.51, so that this sector is categorized as a basic one. Clean water and waste management sector has an LQ value of 1.68, so that this sector is categorized as a basic one. Construction sector has an LQ value of 1.66, so that this sector is categorized as a basic one. Retails and car and motorbike repair shops sector has an LQ value of 1.54, so that this sector is categorized as a basic one. Transportation and warehouse sector have an LQ value of 1.23 , so that this sector is categorized as a basic one. Hotel and restaurant sector have an LQ value of 2.17 , so that this sector is categorized as a basic one. Information dan communication sector has an LQ value of 1.93, so that this sector is categorized as a basic one. Finance and insurance sector have an LQ value of 1.37, so that this sector is categorized as a basic one. Real estate sector has an LQ value of 1.87, so that this sector is categorized as a basic one. Enterprises sector has an LQ value of 0.81 , so that this sector is categorized as a non-basic one. Governmental administration, defense system and social security sector has an LQ value of 1.63 , so that this sector is categorized as a basic one. Educational services sector has an LQ value of 1.63, so that this sector is categorized as a basic one. Health care and social activities sector has an LQ value of 1.30, so that this sector is categorized as a basic one. Uncategorized services sector has an LQ value of 2.54, so that this sector is categorized as a basic one.

Table 3. Sectoral LQs of Baubau City (processed data from Table 1)

\begin{tabular}{|l|r|r|r|r|r|r|r|}
\hline \multirow{2}{*}{ Sectors } & \multicolumn{7}{|c|}{ Years } \\
\cline { 2 - 7 } & 2010 & 2011 & 2012 & 2013 & 2014 & 2015 & 2016 \\
\hline Agriculture & 0.56 & 0.56 & 0.59 & 0.59 & 0.58 & 0.57 & 0.56 \\
Mining & 0.21 & 0.20 & 0.19 & 0.20 & 0.23 & 0.23 & 0.23 \\
Manufacture & 0.66 & 0.67 & 0.71 & 0.69 & 0.71 & 0.72 & 0.69 \\
Electricity and gas & 1.59 & 1.58 & 1.61 & 1.54 & 1.42 & 1.42 & 1.39 \\
Clean water and waste management & 1.60 & 1.71 & 1.75 & 1.73 & 1.67 & 1.69 & 1.65 \\
Constructions & 1.72 & 1.73 & 1.77 & 1.75 & 1.61 & 1.52 & 1.50 \\
Retails and car and motorbike repair & & & & & & & \\
shops & 1.49 & 1.50 & 1.59 & 1.56 & 1.53 & 1.57 & 1.57 \\
Transportation and warehouses & 1.32 & 1.33 & 1.28 & 1.22 & 1.18 & 1.18 & 1.13 \\
Hotels and restaurants & 1.96 & 2.23 & 2.27 & 2.24 & 2.19 & 2.17 & 2.12 \\
Information and communication & 1.91 & 1.97 & 2.01 & 1.95 & 1.88 & 1.91 & 1.89 \\
Finance and insurances & 1.42 & 1.41 & 1.36 & 1.31 & 1.33 & 1.39 & 1.39 \\
Real Estates & 1.78 & 1.81 & 1.90 & 1.90 & 1.90 & 1.93 & 1.87 \\
Enterprises & 0.82 & 0.84 & 0.85 & 0.82 & 0.79 & 0.76 & 0.76 \\
Governmental administration, defense & & & & & & & \\
system and social security & 1.57 & 1.62 & 1.67 & 1.65 & 1.63 & 1.66 & 1.63 \\
Educational services & 1.48 & 1.58 & 1.62 & 1.57 & 1.54 & 1.54 & 1.51 \\
Health care and social activities & 1.25 & 1.32 & 1.37 & 1.36 & 1.29 & 1.27 & 1.26 \\
Uncategorized services & 2.44 & 2.60 & 2.66 & 2.63 & 2.52 & 2.50 & 2.41 \\
\hline
\end{tabular}


Table 4 shows the results of LQ calculations on GDRP of Buton Regency in the period 2010-2016. On average, we can see that agricultural sector has an LQ value of 0.93 , so that this sector is categorized as a non-basic one. Mining sector has an LQ value of 1.76, so that this sector is categorized as a basic one. Manufactured industries sector has an LQ value of 0.50 , so that this sector is categorized as a non-basic one. Electricity and gas sector have an LQ value of 1.01, so that this sector is categorized as a basic one. Clean water and waste management sector has an LQ value of 2.08 , so that this sector is categorized as a basic one. Construction sector has an LQ value of 0.70 , so that this sector is categorized as a non-basic one. Retails and car and motorbike repair shops sector has an LQ value of 0.88 , so that this sector is categorized as a non-basic one. Transportation and warehouse sector has an LQ value of 0.19 , so that this sector is categorized as a non-basic one. Hotel and restaurant sector has an LQ value of 0.25 , so that this sector is categorized as a non-basic one. Information dan Communication sector has an LQ value of 0.24 , so that this sector is categorized as a non-basic one. Finance and insurance sector has an LQ value of 0.32 , so that this sector is categorized as a non-basic one. Real estate sector has an LQ value of 0.54 , so that this sector is categorized as a non-basic one. Enterprise sector has an LQ value of 0.11 , so that this sector is categorized as a non-basic one. Governmental administration, defense system and social security sector has an LQ value of 1.43, so that this sector is categorized as a basic one. Educational service sector has an LQ value of 1.17, so that this sector is categorized as a basic one. Health care and social activities sector has an LQ value of 0.95 , so that this sector is categorized as a non-basic one. Uncategorized services sector has an LQ value of 0.46 , so that this sector is categorized as a nonbasic one.

Table 4. Sectoral LQs of Buton Regency (processed data from BPS Buton 2018)

\begin{tabular}{|l|r|r|r|r|r|r|r|}
\hline \multicolumn{1}{|c|}{ Sectors } & \multicolumn{7}{c|}{ Years } \\
\cline { 2 - 7 } & \multicolumn{1}{|c}{2010} & 2011 & 2012 & 2013 & 2014 & 2015 & 2016 \\
\hline Agriculture & 1.04 & 1.05 & 1.06 & 1.06 & 0.75 & 0.79 & 0.77 \\
Mining & 1.60 & 1.53 & 1.44 & 1.48 & 2.06 & 2.04 & 2.17 \\
Manufacture & 0.53 & 0.54 & 0.58 & 0.59 & 0.43 & 0.43 & 0.42 \\
Electricity and gas & 1.09 & 1.07 & 1.02 & 0.97 & 0.96 & 0.97 & 0.98 \\
Clean water and waste management & 2.09 & 2.03 & 1.93 & 1.95 & 2.13 & 2.18 & 2.23 \\
Constructions & 0.92 & 0.91 & 0.87 & 0.85 & 0.47 & 0.44 & 0.44 \\
Retails and car and motorbike & & & & & & & \\
repair shops & 0.84 & 0.82 & 0.84 & 0.84 & 0.93 & 0.92 & 0.93 \\
Transportation and warehouses & 0.22 & 0.21 & 0.20 & 0.19 & 0.18 & 0.17 & 0.17 \\
Hotels and restaurants & 0.30 & 0.27 & 0.27 & 0.27 & 0.23 & 0.22 & 0.22 \\
Information and communication & 0.32 & 0.31 & 0.31 & 0.32 & 0.15 & 0.14 & 0.14 \\
Finance and insurances & 0.39 & 0.36 & 0.35 & 0.41 & 0.25 & 0.24 & 0.26 \\
Real Estates & 0.70 & 0.70 & 0.70 & 0.70 & 0.33 & 0.34 & 0.35 \\
Enterprises & 0.13 & 0.13 & 0.12 & 0.12 & 0.09 & 0.08 & 0.08 \\
Governmental administration, & & & & & & & \\
defense system and social security & 1.15 & 1.14 & 1.14 & 1.11 & 1.85 & 1.81 & 1.85 \\
Educational services & 1.28 & 1.26 & 1.27 & 1.26 & 1.07 & 1.03 & 1.02 \\
Health care and social activities & 1.07 & 1.03 & 1.06 & 1.07 & 0.82 & 0.81 & 0.83 \\
Uncategorized services & 0.48 & 0.47 & 0.47 & 0.48 & 0.44 & 0.43 & 0.43 \\
\hline
\end{tabular}

Table 5 shows the results of LQ calculations on GDRP of Buton Selatan Regency in the period 20142016. On average, we can see that agricultural sector has an LQ value of 1.21, so that this sector is categorized as a basic one. Mining sector has an LQ value of 1.51, so that this sector is categorized as a basic one. Manufactured industry sector has an LQ value of 0.66 , so that this sector is categorized as a non-basic one. Electricity and gas sector has an LQ value of 0.82 , so that this sector is categorized as a non-basic one. Clean water and waste management sector has an LQ value of 1.46, so that this sector is categorized as a basic one. Construction sector has an LQ value of 1.07, so that this sector is categorized as a basic one. Retails and car and motorbike repair shops sector has an LQ value of 0.67 , so that this sector is categorized as a non-basic one. Transportation and warehouses sector has 
an LQ value of 0.20 , so that this sector is categorized as a non-basic one. Hotel and restaurant sector has an LQ value of 0.24 , so that this sector is categorized as a non-basic one. Information dan Communication sector has an LQ value of 0.51 , so that this sector is categorized as a non-basic one. Finance and insurance sector has an LQ value of 0.38 , so that this sector is categorized as a non-basic one. Real estate sector has an LQ value of 0.04 , so that this sector is categorized as a non-basic one. Enterprises sector has an LQ value of 0.11 , so that this sector is categorized as a non-basic one. Governmental administration, defense system and social security sector has an LQ value of 0.49 , so that this sector is categorized as a non-basic one. Educational services sector has an LQ value of 1.19, so that this sector is categorized as a basic one. Health care and social activities sector has an LQ value of 1.45 , so that this sector is categorized as a basic one. Uncategorized services sector has an LQ value of 0.47 , so that this sector is categorized as a non-basic one.

Table 5. Sectoral LQ of Buton Selatan Regency (processed data from BPS Buton 2018)

\begin{tabular}{|l|c|c|c|c|r|r|r|}
\hline \multicolumn{1}{|c|}{ Sectors } & \multicolumn{5}{c|}{ Years } \\
\cline { 2 - 7 } & 2010 & 2011 & 2012 & 2013 & 2014 & 2015 & 2016 \\
\hline Agriculture & N/A & N/A & N/A & N/A & 1.18 & 1.23 & 1.23 \\
Mining & N/A & N/A & N/A & N/A & 1.50 & 1.46 & 1.58 \\
Manufacture & N/A & N/A & N/A & N/A & 0.68 & 0.67 & 0.62 \\
Electricity and gas & N/A & N/A & N/A & N/A & 0.82 & 0.83 & 0.83 \\
Clean water and waste management & N/A & N/A & N/A & N/A & 1.44 & 1.48 & 1.46 \\
Constructions & N/A & N/A & N/A & N/A & 1.11 & 1.07 & 1.03 \\
Retails and car and motorbike & N/A & N/A & N/A & N/A & 0.69 & 0.68 & 0.65 \\
repair shops & & & & & & & \\
Transportation and warehouses & N/A & N/A & N/A & N/A & 0.20 & 0.20 & 0.19 \\
Hotels and restaurants & N/A & N/A & N/A & N/A & 0.24 & 0.24 & 0.24 \\
Information and communication & N/A & N/A & N/A & N/A & 0.52 & 0.51 & 0.49 \\
Finance and insurances & N/A & N/A & N/A & N/A & 0.40 & 0.39 & 0.36 \\
Real Estates & N/A & N/A & N/A & N/A & 0.04 & 0.05 & 0.05 \\
Enterprises & N/A & N/A & N/A & N/A & 0.12 & 0.11 & 0.11 \\
Governmental administration, & N/A & N/A & N/A & N/A & 0.50 & 0.48 & 0.48 \\
defense system and social security & & & & & & & \\
Educational services & N/A & N/A & N/A & N/A & 1.24 & 1.20 & 1.14 \\
Health care and social activities & N/A & N/A & N/A & N/A & 1.46 & 1.46 & 1.43 \\
Uncategorized services & N/A & N/A & N/A & N/A & 0.46 & 0.46 & 0.49 \\
\hline
\end{tabular}

Table 6 shows the results of LQ calculations on GDRP of Buton Utara in the period 2010-2016. On average, we can see that agricultural sector has an LQ value of 1.61, so that this sector is categorized as a basic one. Mining sector has an LQ value of 0.29 , so that this sector is categorized as a non-basic one. Manufactured industries sector has an LQ value of 0.72 , so that this sector is categorized as a non-basic one. Electricity and gas sector has an LQ value of 0.23 , so that this sector is categorized as a non-basic one. Clean water and waste management sector has an LQ value of 0.28 , so that this sector is categorized as a non-basic one. Construction sector has an LQ value of 1.21, so that this sector is categorized as a basic one. Retails and car and motorbike repair shops sector has an LQ value of 1.10 , so that this sector is categorized as a basic one. Transportation and warehouse sector has an LQ value of 0.31 , so that this sector is categorized as a non-basic one. Hotels and restaurants sector has an LQ value of 0.48 , so that this sector is categorized as a non-basic one. Information dan Communication sector has an LQ value of 0.41 , so that this sector is categorized as a non-basic one. Finance and insurance sector has an LQ value of 0.29 , so that this sector is categorized as a non-basic one. Real estate sector has an LQ value of 1.24, so that this sector is categorized as a basic one. Enterprises sector has an LQ value of 0.32 , so that this sector is categorized as a non-basic one. Governmental administration, defense system and social security sector has an LQ value of 1.48, so that this sector is categorized as a basic one. Educational services sector has an LQ value of 0.92, so that this sector is categorized as a non-basic one. Health care and social activities sector has an LQ 
value of 1.51 , so that this sector is categorized as a basic one. Uncategorized services sector has an LQ value of 0.93 , so that this sector is categorized as a non-basic one.

Table 6. Sectoral LQ of Buton Utara Regency (processed data from BPS Buton Utara 2018)

\begin{tabular}{|l|r|r|r|r|r|r|r|}
\hline \multirow{2}{*}{ Sectors } & \multicolumn{7}{c|}{ Years } \\
\cline { 2 - 7 } & \multicolumn{1}{|c|}{2010} & \multicolumn{1}{c|}{2011} & 2012 & 2013 & 2014 & 2015 & 2016 \\
\hline Agriculture & 1.57 & 1.64 & 1.67 & 1.63 & 1.57 & 1.64 & 1.57 \\
Mining & 0.28 & 0.26 & 0.24 & 0.26 & 0.30 & 0.32 & 0.38 \\
Manufacture & 0.63 & 0.64 & 0.69 & 0.72 & 0.76 & 0.78 & 0.79 \\
Electricity and gas & 0.21 & 0.22 & 0.23 & 0.23 & 0.23 & 0.22 & 0.24 \\
Clean water and waste management & 0.27 & 0.28 & 0.28 & 0.28 & 0.27 & 0.28 & 0.27 \\
Constructions & 1.09 & 1.17 & 1.26 & 1.29 & 1.29 & 1.20 & 1.15 \\
Retails and car and motorbike & 1.02 & 1.09 & 1.16 & 1.15 & 1.09 & 1.08 & 1.07 \\
repair shops & & & & & & & \\
Transportation and warehouses & 0.32 & 0.31 & 0.31 & 0.31 & 0.30 & 0.30 & 0.34 \\
Hotels and restaurants & 0.50 & 0.48 & 0.49 & 0.48 & 0.47 & 0.48 & 0.49 \\
Information and communication & 0.38 & 0.39 & 0.40 & 0.39 & 0.41 & 0.45 & 0.46 \\
Finance and insurances & 0.27 & 0.27 & 0.29 & 0.26 & 0.30 & 0.31 & 0.31 \\
Real Estates & 1.23 & 1.25 & 1.29 & 1.28 & 1.20 & 1.21 & 1.19 \\
Enterprises & 0.33 & 0.33 & 0.33 & 0.33 & 0.31 & 0.30 & 0.30 \\
Governmental administration, & 1.46 & 1.47 & 1.53 & 1.50 & 1.44 & 1.47 & 1.48 \\
defense system and social security & & & & & & & \\
Educational services & 0.96 & 0.94 & 0.96 & 0.92 & 0.88 & 0.90 & 0.88 \\
Health care and social activities & 1.52 & 1.50 & 1.53 & 1.53 & 1.44 & 1.48 & 1.53 \\
Uncategorized services & 0.97 & 0.98 & 0.98 & 0.94 & 0.88 & 0.90 & 0.88 \\
\hline
\end{tabular}

Table 7 shows the results of LQ calculations on GDRP of Buton Tengah Regency in the period 20142016. On average, we can see that agricultural sector has an LQ value of 1.63 , so that this sector is categorized as a basic one. Mining sector has an LQ value of 0.28 , so that this sector is categorized as a non-basic one. Manufactured industries sector has an LQ value of 0.98 , so that this sector is categorized as a non-basic one. Electricity and gas sector has an LQ value of 1.13, so that this sector is categorized as a basic one. Clean water and waste management sector has an LQ value of 2.47, so that this sector is categorized as a basic one. Construction sector has an LQ value of 1.13, so that this sector is categorized as a basic one. Retails and car and motorbike repair shops sector has an LQ value of 0.97 , so that this sector is categorized as a non-basic one. Transportation and warehouse sector has an LQ value of 0.26 , so that this sector is categorized as a non-basic one. Hotels and restaurant sector has an LQ value of 0.38 , so that this sector is categorized as a non-basic one. Information dan communication sector has an LQ value of 0.37 , so that this sector is categorized as a non-basic one. Finance and insurances sector has an LQ value of 0.77 , so that this sector is categorized as a nonbasic one. Real estate sector has an LQ value of 2.28, so that this sector is categorized as a basic one. Enterprises sector has an LQ value of 0.19 , so that this sector is categorized as a non-basic one. Governmental administration, defense system and social security sector has an LQ value of 0.68 , so that this sector is categorized as a basic one. Educational services sector has an LQ value of 1.69, so that this sector is categorized as a basic one. Health care and social activities sector has an LQ value of 1.15 , so that this sector is categorized as a basic one. Uncategorized services sector has an LQ value of 0.56 , so that this sector is categorized as a non-basic one. 
Table 7. Sectoral LQ of Buton Tengah Regency (processed data from BPS Buton 2018)

\begin{tabular}{|c|c|c|c|c|c|c|c|}
\hline \multirow[t]{2}{*}{ Sectors } & \multicolumn{7}{|c|}{ Years } \\
\hline & 2010 & 2011 & 2012 & 2013 & 2014 & 2015 & 2016 \\
\hline Agriculture & N/A & $\mathrm{N} / \mathrm{A}$ & N/A & N/A & 1.57 & 1.66 & 1.66 \\
\hline Mining & N/A & $\mathrm{N} / \mathrm{A}$ & N/A & N/A & 0.27 & 0.27 & 0.30 \\
\hline Manufacture & $\mathrm{N} / \mathrm{A}$ & $\mathrm{N} / \mathrm{A}$ & N/A & $\mathrm{N} / \mathrm{A}$ & 1.01 & 1.01 & 0.92 \\
\hline Electricity and gas & $\mathrm{N} / \mathrm{A}$ & $\mathrm{N} / \mathrm{A}$ & N/A & $\mathrm{N} / \mathrm{A}$ & 1.13 & 1.14 & 1.13 \\
\hline Clean water and waste management & $\mathrm{N} / \mathrm{A}$ & N/A & N/A & $\mathrm{N} / \mathrm{A}$ & 2.42 & 2.56 & 2.44 \\
\hline Constructions & $\mathrm{N} / \mathrm{A}$ & $\mathrm{N} / \mathrm{A}$ & $\mathrm{N} / \mathrm{A}$ & $\mathrm{N} / \mathrm{A}$ & 1.19 & 1.11 & 1.08 \\
\hline $\begin{array}{l}\text { Retails and car and motorbike } \\
\text { repair shops }\end{array}$ & $\mathrm{N} / \mathrm{A}$ & $\mathrm{N} / \mathrm{A}$ & N/A & N/A & 0.99 & 0.97 & 0.95 \\
\hline Transportation and warehouses & $\mathrm{N} / \mathrm{A}$ & $\mathrm{N} / \mathrm{A}$ & N/A & N/A & 0.26 & 0.27 & 0.25 \\
\hline Hotels and restaurants & $\mathrm{N} / \mathrm{A}$ & $\mathrm{N} / \mathrm{A}$ & N/A & $\mathrm{N} / \mathrm{A}$ & 0.39 & 0.38 & 0.37 \\
\hline Information and communication & $\mathrm{N} / \mathrm{A}$ & $\mathrm{N} / \mathrm{A}$ & N/A & $\mathrm{N} / \mathrm{A}$ & 0.37 & 0.38 & 0.36 \\
\hline Finance and insurances & N/A & $\mathrm{N} / \mathrm{A}$ & $\mathrm{N} / \mathrm{A}$ & N/A & 0.78 & 0.78 & 0.74 \\
\hline Real Estates & $\mathrm{N} / \mathrm{A}$ & $\mathrm{N} / \mathrm{A}$ & N/A & $\mathrm{N} / \mathrm{A}$ & 2.22 & 2.31 & 2.32 \\
\hline Enterprises & $\mathrm{N} / \mathrm{A}$ & $\mathrm{N} / \mathrm{A}$ & N/A & N/A & 0.20 & 0.18 & 0.18 \\
\hline $\begin{array}{l}\text { Governmental administration, } \\
\text { defense system and social security }\end{array}$ & N/A & $\mathrm{N} / \mathrm{A}$ & N/A & N/A & 0.68 & 0.68 & 0.68 \\
\hline Educational services & $\mathrm{N} / \mathrm{A}$ & $\mathrm{N} / \mathrm{A}$ & N/A & $\mathrm{N} / \mathrm{A}$ & 1.70 & 1.71 & 1.66 \\
\hline Health care and social activities & $\mathrm{N} / \mathrm{A}$ & $\mathrm{N} / \mathrm{A}$ & N/A & N/A & 1.18 & 1.15 & 1.13 \\
\hline Uncategorized services & $\mathrm{N} / \mathrm{A}$ & N/A & $\mathrm{N} / \mathrm{A}$ & N/A & 0.57 & 0.56 & 0.54 \\
\hline
\end{tabular}

Collaborations between Baubau City and its hinterlands can expand its economy and it also can improve its regional economy. Those collaborations can be made on several sectors such as electricity and gas sector, clean water and waste management sector, construction sector, retails and car and motorbike repair shops sector, transportation and warehouses sector, hotels and restaurants sector, information dan communication sector, finance and insurances sector, real estate sector, governmental administration, defense system and social security sector, educational services sector, health care and social activities sector and uncategorized services sector. On Buton Regency, productions in Baubau City can supply construction sector, retails and car and motorbike repair shops sector, transportation and warehouses sector, hotels and restaurants sector, information dan communication sector, finance and insurances sector, real estate sector, health care and social activities sector and uncategorized services sector. On Buton Utara Regency, productions in Baubau City can supply electricity and gas sector, clean water and waste management sector, transportation and warehouses sector, hotels and restaurants sector, information dan communication sector, finance and insurances sector, educational services sector and uncategorized services sector. On Buton Selatan Regency, productions in Baubau City can supply electricity and gas sector, retails and car and motorbike repair shops sector, transportation and warehouses sector, hotels and restaurants sector, information dan communication sector, finance and insurances sector, real estate sector, governmental administration, defense system and social security sector and uncategorized services sector. On Buton Tengah Regency, productions in Baubau City can supply retails and car and motorbike repair shops sector, transportation and warehouses sector, hotels and restaurants sector, information dan communication sector, finance and insurances sector, governmental administration, defense system and social security sector and uncategorized services sector.

\section{Conclusion}

Baubau city can increase its growth by connecting its economy with its hinterlands. Production in Baubau city should be increased on electricity and gas sector, clean water and waste management sector, construction sector, retails and car and motorbike repair shops sector, transportation and warehouses sector, hotels and restaurants sector, information dan communication sector, finance and insurances sector, real estate sector, governmental administration, defense system and social security sector, educational services sector, health care and social activities sector and uncategorized services sector. 


\section{References}

Ascani, A., Crescenzi, R., Iammarino, S. (2012). Regional Economic Development: A Review. WP1/03 Search Working Paper. Retrieved from http://www.ub.edu/searchproject/wpcontent/uploads/2012/02/WP-1.3.pdf

Berliant, M. (2005). Central Place Theory. Research Gate June 2005. Retrieved from: https://www.researchgate.net/publication/23749688

BPS Baubau (2018). PDRB Kota Baubau Atas Dasar Harga Berlaku Menurut Lapangan Usaha Tahun $2010 \quad-2016 \quad$ (Juta Rupiah). Retrieved from https://baubaukota.bps.go.id/subject/52/produk-domestik-regionalbruto.html\#subjekViewTab3

BPS Buton (2018). PDRB Atas Dasar Harga Berlaku menurut Pengeluaran Kabupaten Buton Selatan (Juta Rupiah) 2014-2016. Retrieved from https://butonkab.bps.go.id/dynamictable/2017/07/31/30/pdrb-atas-dasar-harga-berlakumenurut-pengeluaran-kabupaten-buton-selatan-juta-rupiah-2014-2016.html

BPS Buton (2018). PDRB Kabupaten Buton Atas Dasar Harga Berlaku Menurut Lapangan Usaha Tahun 2010-2016 (Juta Rupiah). Retrieved from https://butonkab.bps.go.id/dynamictable/2017/07/05/7/pdrb-kabupaten-buton-atas-dasarharga-berlaku-menurut-lapangan-usaha-tahun-2010-2016-juta-rupiah-.html

BPS Buton (2018). PDRB Kabupaten Buton Tengah Atas Dasar Harga Berlaku Menurut Lapangan Usaha Tahun 2014-2016 (Juta Rupiah). Retrieved from https://butonkab.bps.go.id/dynamictable/2017/07/05/13/pdrb-kabupaten-buton-tengah-atasdasar-harga-berlaku-menurut-lapangan-usaha-tahun-2014-2016-juta-rupiah-.html

BPS Buton Utara (2018). PDRB Kabupaten Buton Utara Atas Dasar Harga Berlaku Menurut Lapangan Usaha Tahun 2010-2016 (Juta Rupiah). Retrieved from https://buturkab.bps.go.id/dynamictable/2017/07/04/4/pdrb-kabupaten-buton-utara-atas-dasarharga-berlaku-menurut-lapangan-usaha-juta-rupiah-2010-2016-.html

Hanif, Md. A., Tabassum, A., Hauque, A. M., Hossain, Md. R., Jahan, S., Debnath, A. K. (2015). Determination of Location Quotient (LQ) of Districts of Bangladesh based on Level of Urbanization and their Regionalization to Study the Regional Disparities based on Indicators of Urban Area of Bangladesh. European Academic Research Vol.III, Issue 2/May 2015. https://www.researchgate.net/publication/281462793

OECD (2008). Port Competition and Hinterland Connections: Summary and Conclusion. Discussion Paper No. 2008-19 October 2008. Joint Transport Research Centre Round Table Paris 10-11 April 2008. Retrieved from: https://www.oecdilibrary.org/docserver/235100656678.pdf?expires $=1541142618 \& \mathrm{id}=\mathrm{id} \&$ accname=guest\&che cksum=DC5BAD91E670A5258AC5E67D22C5DEEA

Srotebeck, F. (2010). The Location Quotient-Assembly and Application of Methodological Enhancements. MPRA Paper No. 47988. Retrieved from: http://mpra.ub.unimuenchen.de/47988/

Visser, J., Konings, R., Pielage, B. J., Wiegmans, B. (2007). A New Hinterland Transport Concept for The Port of Rotterdam: Organizational and/or Technological Challenges? Retrieved from: https://ageconsearch.umn.edu/bitstream/207936/2/2007 9B_Hinterland_paper.pdf

Welman L., Ferreira S. L. A. (2016). The Co-evolution of Saldanha Bay (Town and Hinterland) and its Port. Local Economy: The Journal of the Local Economy Policy Unit Vol.31. Sage Journals. Retrieved from: https://doi.org/10.1177/0269094215623849 